\title{
Bibliography
}

Ahern, B. (2005) Interview on: News at One, RTÉ Radio 1, 8 July, 1320 hrs.

Air Corps (1998) Airpower Strategies for the New Century, Dublin: Air Corps.

Air Corps (1999) Airpower Options for the New Century, Dublin: Air Corps.

Allen, G. (1999) The Garda Síochána: Policing Independent Ireland 1922-82. Dublin: Gill and Macmillan.

Allison, G. and P. Zelikow (1999) Essence of Decision: Explaining the Cuban Missile Crisis, 2nd edn, New York: Addison Wesley Longman.

Alvesson, M. (2003) 'Methodology for Close up Studies', Higher Education, Vol. 46 (2), 167-93.

An Cosantóir (2005) 'The Need to Know', December, 28-30.

Altran, S. (2003) 'Genesis and Future of Suicide Terrorism', Understanding Suicide Terrorism Discussion Site [online] July 1, available at www.interdisciplines.org/ terrorism/papers/1 [accessed 28 Oct. 2005].

Anderson, P. (2001) 'Health Minister apologises for radio statements', Irish Times Breaking News, 28 Sept., available at www.irishtimes.com/newspaper/breaking/2001/0928/breaking10.htm [accessed 2 Feb. 2007].

Archer, C. and N. Nugent (2002) 'Introduction: Small States and the European Union', Current Politics and Economics of Europe, Vol. 11 (1), 1-10.

Arksey, H. and P. Knight (1999) Interviewing for Social Scientists: An Introductory Resource with Examples, London, Thousand Oaks, New Delhi: Sage.

Armstrong, A. (2004) 'Operation Dutch Elm', An Cosantóir, May, 28-30.

Arnold, B. (1994) Haughey: His Life and Unlucky Deeds, paperback edn, London: Harper Collins.

BBC News [online] (2001) 'Pressure builds up over policing', 24 Feb., available at http://news.bbc.co.uk/2/hi/uk_news/northern_ireland/1187911.stm [accessed 3 Feb. 2007].

BBC News [online] (2004) '20,000 posts go in defence cuts', 21 July, available at http://news.bbc.co.uk/2/hi/uk_news/politics/3912283.stm [accessed 22 July 2004]. 
BBC News [online] (2005) 'Blair defends NI military moves', 4 Aug., available at http://news.bbc.co.uk/2/hi/uk_news/northern_ireland/4746059.stm [accessed 4 Aug. 2005].

Betts, R.K. (2002) 'Fixing Intelligence', Foreign Affairs, Jan./Feb., Vol. 81 (1), 43-59.

Bhreathnach, A. (2002) 'Frank Aiken: European federation and the UN', Irish Studies in International Affairs, Vol. 13, 237-49.

Blair, T. (2006) Interview on: Nine O’ Clock News, RTÉ 1, 10 Nov., 2100 hrs.

Booth, K. (1991) 'Security in Anarchy: Utopian Realism in Theory and Practice, International Affairs, 67 (3), 527-45.

Bourke, W. (2007) 'Tomorrow's Forces Today', An Cosantóir, Aug., 6-7.

Bowyer Bell, J. (1996) In Dubious Battle: The Dublin and Monaghan Bombings 1972-1974, Dublin: Poolbeg.

Boyd-Barrett, R. (2005) 'Like it or not, we are up to our neck in the Iraq war', Irish Times [online] 10 Aug., available at www.irishtimes.com [accessed 1 Feb. 2007].

Boyle, R. and P.C. Humphreys (2001) A New Change Agenda for the Irish Public Service, Dublin: Institute of Public Administration.

Boyne, S. (2006) Gunrunners: The Covert Arms Trail to Ireland, Dublin: The O’Brien Press.

Bracken, A. (2005) 'Asylum families kept apart', Irish Times [online], 24 June, available at www.irishtimes.com [accessed 2 Feb. 2007].

Brady, C. (2000) Guardians of the Peace, 2nd edn, London: Prendeville.

Brady, C. (2004) 'It's time to remove the political handcuffs from the Garda Síochána', Irish Times, 11 Jan.

Brady, T. (2002) 'Security alert sparks new fear of "soft" target attack', Irish Independent [online], 11 Sept., available at www.unison.ie/irish_independent [accessed 3 May 2006].

Brady, T. (2004a) 'Suspects to be monitored as security for Bush tightens', Irish Independent [online], 23 June, available at www.unison.ie/irish_independent [accessed 25 June 2004].

Brady, T. (2004b) 'Defence Forces to undergo terrorism drills', Irish Independent [online], 13 Dec., available at www.unison.ie/irish_independent [accessed 18 Dec. 2004].

Brady, T. (2004c) 'Scores of illegals deported after raids', Irish Independent [online], 12 Dec., available at www.unison.ie/irish_independent [accessed 12 Aug. 2005].

Brady, T. (2005a) 'Saddam's fighters here for a holiday', Irish Independent [online], 22 Oct., available at www.unison.ie/irish_independent [accessed 24 Oct. 2005].

Brady, T. (2005b) 'Terror threat prompts Army to build-up intelligence, Irish Independent [online], 1 Dec., available at www.unison.ie/irish_independent [accessed 1 Dec. 2005].

Brady, T. (2006a) 'Ireland joins EU borders agency in crime fight', Irish Independent [online], 22 Sept., available at www.unison.ie/irish_independent [accessed 23 Sept. 2006].

Brady, T. (2006b) 'Chemical Willie goes into crisis mode ... silently', Irish Independent [online], 17 Nov., available at www.unison.ie/irish_independent [accessed 17 Nov. 2006].

Brady, T. (2007) 'Close watch on terror threat', Irish Independent [online], 16 July, available at www.independent.ie [accessed 17 July 2007]. 
Brady, T. (2009) 'Reservists overseas missions put on hold', Irish Independent [online], 3 Apr., available at www.independent.ie/national-news/reservistsoverseas-missions-put-on-hold-1696804.html [accessed 6 Apr. 2009].

Brennan, C. (2007) 'Deering to head rights authority', Irish Times [online], 12 Jan., available at www.irishtimes.com [accessed 4 Feb. 2007].

Brennan, M. (2008) 'Priests to take on "immigration role" with foreign couples, Irish Independent [online], 4 Feb., available at www.indepedendent.ie [accessed 4 Feb. 2008].

Brennock, M. (2000a) 'Defence plan to be altered to reassure military', Irish Times [online] 1 Mar., available at www.irishtimes.com [accessed 3 Feb. 2007].

Brennock, M. (2000b) 'Minister issues "warning for the future" to Army leaders', Irish Times [online], 6 Mar., available at www.irishtimes.com [accessed 3 Feb. 2007].

Brennock, M. (2001) 'McCreevy forced to scale down spending plans', Irish Times [online], 16 Nov., available at www.irishtimes.com [accessed 20 Nov. 2006].

Brennock, M. (2004) 'Poll highlights lack of confidence in the Garda', Irish Times [online], 10 Feb., available at www.irishtimes.com [accessed 12 Nov. 2005].

Brown, C. (1997) Understanding International Relations, London: Macmillan Press.

Browne, V. (1980) 'Arms Crisis 1970: The Inside Story', Magill, May, 33-56.

Browne, V. (2000) 'New security Bill gives too much power to the Garda', Irish Times [online], 2 Sept., available at www.irishtimes.com [accessed 7 Oct. 2006].

Bulmer, S. and M. Burch (1998) 'Organizing for Europe: Whitehall, The British State and European Union', Public Administration, Vol. 76, 601-628.

Burchill, S. (1997) 'Liberal Internationalism', in S. Burchill, A. Linklater, R. Devetak, M. Paterson and J. True (eds), Theories of International Relations, Hampshire and London: Macmillan, 28-66.

Buzan, B. (1991) People, States and Fear: An Agenda for International Security Studies in the Post-Cold War Era, 2nd edn, Hemel Hempstead: Harvester Wheatsheaf.

Buzan, B. (2002) 'Implications of September 11 for the Study of International Relations', in B. Sundelius (ed.), The Consequences of September 11: A Symposium on the Implications for the Study of International Relations, Stockholm: The Swedish Institute for International Affairs, 25-41.

Buzan, B., Jones, C. and Little, R. (1993) The Logic of Anarchy: Neorealism to Structural Realism, New York: Columbia University Press.

Byrne, D. (2002) Interpreting the Real and Describing the Complex: Why We Have to Measure, London, Thousand Oaks, New Delhi: Sage.

Campbell, L. (2003) 'Britain's Changing Attitude to Irish Neutrality 1938 to 1950', Defence Forces Review 2003, Vol. 1, 29-34.

Carter, A.B. (2001) 'The Architecture of government in the Face of Terrorism', International Security, Vol. 26 (3), 5-23.

Central Statistic Office (2004), Quarterly National Household Survey [online], July, available at www.cso.ie/qnhs/pub_rel_qnhs.htm [accessed 30 July 2004].

Cha, V. (2000) 'Abandonment, Entrapment and Neoclassical Realism in Asia: The United States, Japan, and Korea', International Studies Quarterly, Vol. 44 (2), 261-91.

Chaulia S. (2003) 'September 11 in International Relations Theory', Kashmir Herald [online], 2 Aug., available at: www.kashmirherald.com/featuredarticle/ september1lininternationalrelationstheory.html [accessed 2 Feb. 2004]. 
Chomsky, N. (2002) 'Who Are The Global Terrorists?', in K. Booth and T. Dunne (eds), Worlds in Collision: Terror and the Future of Global Order, Hampshire: Palgrave Macmillan, 128-37.

Clare Champion, 'Councillors defend US use of Shannon', 18 Nov. 2002, p. 6.

Clonan, T. (2005) 'What if Ireland were targeted by terrorists?' Irish Times [online], 20 Mar., available at www.irishtimes.com [accessed 20 Mar. 2005].

Clutterbuck, R. (1990) Terrorism and Guerrilla Warfare: Forecasts and Remedies. New York and London: Routledge.

Collins, G. (2007) 'Emergency centre "not a government bunker", Irish Independent [online], 8 Mar., available at www.unison.ie [accessed 8 Mar. 2007].

Collins, S. (2007) 'Irish will need passports to visit Britain from 2009', Irish Times, 24 Oct., p. 1.

Collins, S. and D. Keenan (2007) 'Taoiseach confirms electronic border plan', Irish Times [online], 25 Oct., available at www.irishtimes.com [accessed 25 Oct. 2007].

Commission of Investigation into The Dublin and Monaghan Bombings of 1974 (2007) Final Report March 2007 [online], available at http://193.178.1.117/attached_files/Pdf\%20files/COMMISSION\%20OF\%20INVESTIGATION\%20F INAL\%20REPORT.doc [accessed 01 Sept. 2007].

Connect (2006) 'Cav Go Mowag', 11 (2), 1.

Cooney, J. (2007) 'Taoiseach denounces “illiberal secularist voices” in democracy', Irish Independent [online] 27 Feb., available at www.unison.ie [accessed 28 Feb. 2007].

Corbin, J. (2002) The Base: In Search of al-Qaeda - The Terror Network that Shook the World, London: Simon and Schuster.

Coughlan, M. (2005) Interview on: Morning Ireland, RTÉ Radio 1, 14 Oct., 0810 hrs.

Coulter, C. (2000) 'UNHRC to question use of the Offences Against the State Act', Irish Times [online], 21 June, available at www.irishtimes.com [accessed 7 Oct. 2006].

Coulter, C. (2002) 'The law falls into disrepute', Irish Times [online], 28 Dec., available at www.irishtimes.com [accessed 14 Jan. 2005].

Coulter, C. (2003a) 'Time to hold the Garda to account', Irish Times [online], 19 July, available at www.irishtimes.com [accessed 19 July 2003].

Coulter, C. (2003b) 'Anti-terrorism legislation causes concern', Irish Times [online], 27 Mar., available at www.irishtimes.com [accessed 12 Apr. 2005].

Coulter, C. (2004a) 'Opportunity to reform Garda Síochána must not be missed', Irish Times [online], 17 Jan., available at www.irishtimes.com [accessed 17 Jan. 2004].

Coulter, C. (2004b) 'Bill to deal with terrorist offences before committee', Irish Times [online], 4 Nov., available at www.irishtimes.com [accessed 6 Nov. 2004].

Coulter, C. (2004c) 'Government has failed to examine why immigrants are coming here', Irish Times [online], 17 June, available at www.irishtimes.com [accessed 18 June 2004].

Coulter, C. (2005) 'Plans to overhaul law for immigrants published', Irish Times [online], 13 Apr., available at www.irishtimes.com [accessed 14 Aug. 2005].

Coulter, C. (2008) 'Immigration Bill change urged', Irish Times [online], 3 Apr., available at www.irishtimes.com [accessed 3 Apr. 2008].

Cowen, B. (2001) 'Opening Address: Challenges to Liberal Institutionalism', Irish 
Studies in International Affairs, Vol. 12, 1-5.

Cudmore, T. (2003) 'Will Defence lead National Security Planning for Ireland in the 21st Century?' Defence Forces Review 2003, Vol. 1, 55-63.

Cusack, J. (2001a) 'Army special forces is expanded for anti-terrorist operations', Irish Times [online], 22 Sept., available at www.irishtimes.com [accessed 22 Sept. 2002].

Cusack, J. (2001b) 'Decommissioning pace forced by IRA's Colombian links', Irish Times [online], 27 Oct., available at www.irishtimes.com [accessed 12 Feb. 2005].

Cusack, J. (2002a) 'Short-lived turnaround in fortunes of Defence Forces', Irish Times [online], July 06, available at www.irishtimes.com [accessed 4 Feb. 2004].

Cusack, J. (2002b) 'FBI turns spotlight on al-Qaeda's Dublin operations', Irish Times [online], 31 July, available at www.irishtimes.com [accessed 1 Aug. 2002].

Cusack, J. and M. Brennock (2002) 'Surprise as Smith cancels Sikorski helicopter deal', Irish Times [online] 6 July, available at www.irishtimes.com [accessed 4 Feb. 2004].

Deegan, G. (2005) 'Increase in US troop traffic at Shannon', Irish Times [online], 13 July, available at www.irishtimes.com [accessed 15 Apr. 2006].

Deegan, G. (2006) 'Record numbers of US troops use Shannon', Irish Times [online], 8 July, available at www.irishtimes.com [accessed 6 Sept. 2006].

Deegan, G. (2008) 'Nearly 67,000 US troops passed through Shannon in JanuaryMarch', Irish Times [online], 11 Apr., available at www.irishtimes.com [accessed 12 Apr. 2008].

Defence Forces (1999) Annual Report 1999, Dublin: Defence Forces.

Defence Forces (2000) Annual Report 2000, Dublin: Defence Forces.

Defence Forces (2001a) Annual Report 2001, Dublin: Defence Forces.

Defence Forces (2001b) Defence Forces Strategy Statement 2001-2004, Dublin: Defence Forces.

Defence Forces (2001c) Defence Forces Estimates 2001 [restricted], Dublin: Defence Forces.

Defence Forces (2002a) Annual Report 2002, Dublin: Defence Forces.

Defence Forces (2002b) Defence Forces Estimates 2002 [restricted], Dublin: Defence Forces.

Defence Forces, Director of Personnel (2002) Human Resource Management Annual Report 2002, Dublin: Defence Forces.

Defence Forces (2003a) Annual Report 2003, Dublin: Defence Forces.

Defence Forces (2003b) Defence Forces Estimates 2003 [restricted], Dublin: Defence Forces.

Defence Forces (2004a) Annual Report 2004, Dublin: Defence Forces.

Defence Forces (2004b) Reserve Defence Forces Implementation Plan, Dublin: Defence Forces.

Der Derian, J. (2002) 'In Terrorem: Before and After 9/11', in K. Booth and T. Dunne (eds), Worlds in Collision: Terror and the Future of Global Order, Hampshire: Palgrave Macmillan, 101-17.

DeVault, M. L. (2002) 'Talking and Listening from Women's Standpoint: Feminist Strategies for Interviewing and Analysis', in D. Weinberg (ed.), Qualitative Research Methods, Maiden, MA: Blackwell.

Devetak, R. (1996) 'Critical Studies', in S. Burchill, A. Linklater, R. Devetak, M. Paterson and J. True (eds), Theories of International Relations, Hampshire and 
London: Macmillan, 145-78.

Devetak, R. (1996) 'Postmodernism', in S. Burchill, A. Linklater, R. Devetak, M. Paterson, and J. True (eds), Theories of International Relations, Hampshire and London: Macmillan, 179-209.

De Vries, G. (2005) 'Opening address - The European Union's role in the fight against terrorism' Irish Studies in International Affairs, Vol. 16, 3-9.

Dixon, P. (2001) Northern Ireland: The Politics of War and Peace, London: Palgrave.

Donnelly, K. (2007) 'Schools warn of “white flight” of students', Irish Independent [online], 20 Oct., available at www.independent.ie [accessed 20 Oct. 2007].

Donohue, M. (2002a) 'Ministers given until Friday to find $€ 100 \mathrm{~m}$ more in cuts', Irish Times [online], 22 July, available at www.irishtimes.com [accessed 4 Feb. 2004].

Donohue, M. (2002b) 'State ponders option of leasing aircraft', Irish Times [online], 15 July, available at www.irishtimes.com [accessed 6 Mar. 2004].

Donohue, M. (2006a) 'State set to announce plans for dialogue with churches', Irish Times [online], 15 Nov., available at www.irishtimes.com [accessed $27 \mathrm{Dec}$. 2006].

Donohue, M. (2006b) “Widespread” collusion by British forces behind atrocities', Irish Times [online], 30 Nov., available at www.irishtimes.com [accessed 3 Feb. 2007].

Dooley, C. (2002) 'Government criticised for abandoning gardaí promise', Irish Times [online], 24 Dec., available at www.irishtimes.com [accessed 20 Nov. 2006].

Downes, J. (2005a) 'Pakistani students missing from Waterford college', Irish Times [online], 21 Jul, available at www.irishtimes.com [accessed 23 July 2005].

Downes, J. (2005b) 'Dialogue is needed, says Irish Islamic cleric', Irish Times [online], 8 Aug., available at www.irishtimes.com [accessed 8 Aug. 2005].

Doyle, J. (1999) 'Governance and Citizenship in Contested States: The Northern Ireland Peace Agreement as Internationalised Governance', Irish Studies in International Affairs, Vol. 10, 201-19.

Duggan, J.P. (1991) A History of the Irish Army, Dublin: Gill and Macmillan.

Dunne, D. and G. Kerrigan (1984) Round Up the Usual Suspects: The Cosgrave Coalition and Nicky Kelly, Dublin: Magill.

Edwards, E. (2007a) 'Gardaí unable to apologise for errors - report', Irish Times Breaking News [online], 2 Aug., available at www.irishtimes.com [accessed 9 Aug. 2007].

Edwards, E. (2007b) 'Conroy rejects criticisms of Garda', Irish Times Breaking News [online], 2 Aug., available at www.irishtimes.com [accessed 9 Aug. 2007].

Einav, S., Z. Feigenberg, C. Weissman, D. Zaichik, G. Caspi, D. Kotler and H.R. Freund (2004) 'Evacuation priorities in mass casualty terror-related events: implications for contingency planning', Annals of Surgery, Vol. 239 (3), 304-10.

English, R. (2003) Armed Struggle: A History of the IRA, London, Basingstoke and Oxford: Macmillan.

European Union, European Council (2001) 'Conclusions and Plan of Action of the Extraordinary European Council Meeting on 21 September 2001' [online], available at http://ue.eu.int/cms3_fo/showPage.ASP?id=406\&lang=en\&mode =g [accessed 8 Dec. 2004].

European Union, High Representative for the Common Foreign and Security 
Policy (2003) A Secure Europe in the Better World [online], available at http:// ue.eu.int/cms3_fo/showPage.ASP?id=406\&lang=en\&mode $=g$ [accessed 3 Dec. 2004].

European Union, European Council (2004a) 'Brief Note on Counter Terrorism' [online], 16 Dec., available at http://ue.eu.int/cms3_fo/showPage.ASP?id=406 \&lang=en\&mode $=$ g [accessed 13 Jan. 2005].

European Union, European Council (2004b) Conceptual Framework on the European Security and Defence Policy (ESDP) Dimension of the Fight Against Terrorism [online], available at http://ue.eu.int/cms3_fo/showPage.ASP?id=40 6\&lang $=$ en $\&$ mode $=\mathrm{g}$ [accessed 9 Dec. 2004].

European Union, European Council (2004c) 'Declaration on Combating Terrorism' [online fact sheet], 26 June, available at http://ue.eu.int/cms3_fo/showPage. ASP id $=406 \&$ lang $=$ en $\&$ mode $=g$ [accessed 9 Dec. 2004].

European Union, European Council (2004d) 'Adoption of Council conclusions on prevention, preparedness and response to terrorist attacks' [online], available at http://ue.eu.int/cms3_fo/showPage.ASP?id=406\&lang=en\&mode=g [accessed 10 Dec. 2004].

European Union, European Counter-Terrorism Coordinator (2004) Interim Report on the Evaluation of National Anti-Terrorist Arrangements [online], available at http://ue.eu.int/cms3_fo/showPage.ASP?id=406\&lang=en\&mode=g [accessed 12 Dec. 2004].

European Union, Dutch Presidency and Counter Terrorism Coordinator (2004) 'The fight against terrorism: Note by the Presidency in association with the Counter-Terrorism Co-ordinator' [online], available at http://ue.eu.int/cms3_ fo/showPage.ASP?id=406\&lang=en\&mode=g [accessed 13 Jan. 2005].

European Union, Counter Terrorism Coordinator (2005) Implementation of the Action Plan to Combat Terrorism [online], available at http://ue.eu.int/cms3_ fo/showPage.ASP?id=406\&lang=en\&mode=g [accessed 12 Apr. 2006].

European Union, UK Presidency and Counter Terrorism Coordinator (2005a) EU emergency and crisis co-ordination arrangements [online], available at http:// ue.eu.int/cms3_fo/showPage.ASP?id=406\&lang=en\&mode $=g$ [accessed 18 Apr. 2006].

European Union, UK Presidency and Counter Terrorism Coordinator (2005b) The European Counter-Terrorism Strategy [online], available at http://ue.eu.int/ cms3_fo/showPage.ASP?id=406\&lang=en\&mode=g [accessed 12 Apr. 2006].

European Union, UK Presidency and Counter Terrorism Coordinator (2005c) The European Union Strategy for Combating Radicalisation and Recruitment to Terrorism [online], available at http://ue.eu.int/cms3_fo/showPage.ASP?id=40 6\&lang $=$ en $\&$ mode $=$ g [accessed 12 Apr. 2006].

Fahy, D. and E. Donnellan (2001) 'Martin's assurance on iodine supply incorrect', Irish Times [online], 28 Sept., available at www.irishtimes.com [accessed 4 Feb. 2007].

Fanning, R. (1978) The Irish Department of Finance, 1922-58, Dublin: Institute of Public Administration.

Fanning, R. (1998) 'Small states, large neighbours: Ireland and the United Kingdom', Irish Studies in International Affairs, Vol. 9, 21-9.

Fanning, R. (2001) 'Playing it cool: The response of the British and Irish governments to the crisis in Northern Ireland, 1968-9', Irish Studies in International Affairs, Vol. 12, 57-85. 
Farrell, T. (1997) “The model army”: military imitation and the enfeeblement of the army in post-revolutionary Ireland, 1922-42', Irish Studies in International Affairs, Vol. 8, 111-27.

Farrell, T. (2001) 'Transnational Norms and Military Development: Constructing Ireland's Professional Army', European Journal of International Relations, Vol. 7 (1), 63-102.

Fine Gael (2004) One in Five Crimes Not Reported, One in Three Among Young People - Deasy, [online press release], 27 Feb., available at www.finegael.ie/fine-gaelnews.cfm [accessed 2 Nov. 2005].

Fisk, R. (1983) In Time of War: Ireland, Ulster and the Price of Neutrality 1939-45, Dublin: Gill and Macmillan.

Fitzgerald, G. (1998) 'The origins, development and present status of Irish "neutrality"', Irish Studies in International Affairs, Vol. 9, 11-19.

Fitzgerald, J. (2005) 'Extra security channel to reduce delays at airport', Irish Times [online], 24 June, available at www.irishtimes.com [accessed 25 June 2005].

Fitzgerald, M. (2007) 'English classes urged for migrants', Irish Times [online], 12 Sept., available at www.irishtimes.com [accessed 12 Sept. 2007].

Fitzgerald, T.P. (2008) 'The Morris Tribunal of Inquiry and the Garda Síochána, Communique, available at www.garda.ie/Documents/User/ Communique\%20Mar\%2008.pdf [accessed 4 Apr. 2009].

Flynn, P. (2005) 'Airport in Crisis', The Clare People, 2 Aug., 1.

Foley, F. (2003) 'North-South Relations and the Outbreak of the Troubles in Northern Ireland, 1968-9: the Response of the Irish Press', Irish Studies in International Affairs, Vol. 14, 9-31.

Fontana, A. and J. Frey (1994) 'Interviewing: The art of science', in N. Denzin and Y. Lincoln (eds), Handbook of Qualitative Research, London, Thousand Oaks, New Delhi: Sage.

Foucault, M. (1980) Power/Knowledge, Hemel Hempstead: Harvester Wheatsheaf. Garda Síochána (2000) Policing Plan 2000, Dublin: Garda Síochána.

Garda Síochána (2001) Policing Plan 2001, Dublin: Garda Síochána.

Garda Síochána (2002) Policing Plan 2002, Dublin: Garda Síochána.

Garda Síochána (2003) Policing Plan 2003, Dublin: Garda Síochána.

Garda Síochána (2004) Garda Public Attitudes Survey 2004 [online], available at www.garda.ie/angarda/othdocs.html [accessed 1 Nov. 2005].

Garda Síochána (2005) Garda Public Attitudes Survey 2005 [online], available at www.garda.ie/angarda/othdocs.html [accessed 1 Nov. 2005].

Garda Síochána (2008) Communique, March, 1-31.

Garda Síochána Complaints Board (1998) Annual Report 1998, Dublin: Garda Síochána Complaints Board.

Gearson, J. (2002) 'The Nature of Modern Terrorism', in L. Freedman (ed.), Superterrorism: Policy Responses, London: Blackwell, 7-24.

Gillespie, P. (1996) 'Ireland in the New World Order: Interests and Values in the Irish government's White Paper on Foreign Policy', Irish Studies in International Affairs, Vol. 7, 143-56.

Goldstone, K. (2000) “Benevolent Helpfulness"? Ireland and the International Reaction to Jewish Refugees', in M. Kennedy and J.M. Skelly (eds), Irish Foreign Policy 1919-1966: From Independence to Internationalism, Dublin: Four Courts Press, 116-36.

Gray, C. (2002) 'World Politics as Usual after September 11', in K. Booth and 
T. Dunne (eds), Worlds in Collision: Terror and the Future of Global Order, Hampshire: Palgrave Macmillan, 226-34.

Gray, T. (1997) The Lost Years: The Emergency in Ireland 1939-45, London: Warner Books.

Green Party (2005) 'Apr. 05 Garda Síochána Bill’ [Dáil speech], 21 Apr., available at www.greenparty.ie/en/in_the_dail/speeches/21_apr_05_garda_s_och_na_bill [accessed 31 Jan. 2007].

Gutteridge, W. (ed.) (1986) The New Terrorism, London: Mansell.

Hall, P.A. and R.C.R. Taylor (1996) 'Political Science and the Three New Institutionalisms', Political Studies, Vol. 44, 936-57.

Harvey, D. (2001) Peacekeepers: Irish Soldiers in the Lebanon, Cork: Merlin.

Haughey, N. (2001a) 'Immigration officers to be part of Garda bureau', Irish Times [online], 5 Feb., available at www.irishtimes.com [accessed 10 Oct. 2005].

Haughey, N. (2001b) 'More staff for checks on entry to State', Irish Times [online], 10 May, available at www.irishtimes.com [accessed 10 Oct. 2005].

Harrison, H. (1942) The Neutrality of Ireland: Why it was Inevitable, London: Robert Hale Limited.

Heaslip, R.E.M. (2007) 'Ireland's First Engagement in United Nations Peacekeeping Operations: An Assessment', Defence Forces Review, Vol. 4, 83-93.

Heffernan, B. (2006) 'Worrying rise in abuse of migrants reported', Irish Independent [online], 8 May, available at www.unison.ie/irish_independent [accessed 8 May 2006].

Hennessy, M. (2001) 'Garda, prisons, courts all due for extra spending', Irish Times [online], 16 Nov., available at www.irishtimes.com [accessed 20 Nov. 2006].

Hennessy, M. (2003) 'Cutbacks lead to reduction in Swiss armoured vehicles order', Irish Times [online], 3 Jan., available at www.irishtimes.com [accessed 18 June 2005].

Hennessy, M. (2004a) 'Tribunal finds two gardaí offered “a tissue of lies”, Irish Times [online], 16 July, available at www.irishtimes.com [accessed 16 July 2004].

Hennessy, M. (2004b) 'Time wasted getting to the bottom of lies', Irish Times [online], 16 July, available at www.irishtimes.com [accessed 16 July 2004].

Hennessy, M. (2008) 'Checks between the North and rest of UK on way' Irish Times [online], 28 July, available at www.irishtimes.com [accessed 3 Apr. 2009].

Hennessy, M. (2006) 'Brennan warns of French-style race riots', Irish Times [online], 27 Dec., available at www.irishtimes.com [accessed 27 Dec. 2006].

Henry, G.T. (1998) 'Practical Sampling', in L. Bickerman and D.J. Rog (eds), Handbook of Applied Social Research Methods, Thousand Oaks, London, New Delhi: Sage, pp. 101-26.

Herman, M. (1996) Intelligence Power in Peace and War, Cambridge: Cambridge University Press.

Herman, M. (1999) 'Intelligence services and ethics in the new millennium', Irish Studies in International Affairs, Vol. 10, 249-65.

Herman, M. (2001) Intelligence Services in the Information Age: Theory and Practice, London: Frank Cass.

Hills, M. and R. Holloway (2002) 'Competing for media control in an age of asymmetric warfare', Jane's Intelligence Review [online], 1 May, available at www. janes.com [accessed 11 Mar. 2003].

Hogan, T. (2002) 'Thousands didn't receive anti-radiation tablets', Irish Independent [online], 3 Sept., available at www.unison.ie/irish_independent [accessed 18 


\section{Mar. 2003].}

Hogan, T. (2004) 'Firefighters "not prepared" to deal with terror atrocity', Irish Independent [online], 14 Apr., available at www.unison.ie/irish_independent [accessed 17 Apr. 2004].

Hogan, T. (2006) 'Disaster response unit given green light', Irish Independent [online], 04 May, available at www.unison.independent.ie [accessed 4 May 2006].

Holland, K. (2005) 'government policies fuelling racism - report', Irish Times [online], 11 Jan., available at www.irishtimes.com [accessed 10 Oct. 2005].

Holland, K. (2006a) 'New plan to coordinate emergency services', Irish Times [online], 12 June, available at www.irishtimes.com [accessed 2 Feb. 2007].

Holland, K. (2006b) 'Non-EU nationals with study plan "devastated” by barriers', Irish Times [online], 21 Oct., available at www.irishtimes.com [accessed 21 Oct. 2006].

Horgan, J. (1999) 'Irish Foreign Policy, Northern Ireland, Neutrality and the Commonwealth: the Historical Roots of a Current Controversy', Irish Studies in International Affairs, Vol. 10, 135-47.

Humphreys, J. (2005) 'Immigrant level moves towards 10\%', Irish Times [online], 15 Sept., available at www.irishtimes.com [accessed 15 Sept. 2005].

Huntington, Samuel P. (1996) The Clash of Civilizations and the Remaking of World Order, New York: Simon and Schuster.

Ireland, Dáil Debates (1999) [online] 9 Dec., available at www.irlgov.ie/debates99/9dec99/sect6.htm [accessed 7 Feb. 2007].

Ireland, Dáil Debates (2001) [online] 23 May, available at www.irlgov.ie/debates01/23may/sect3.htm [accessed 5 Feb. 2007].

Ireland, Dáil Debates (2004) Vol. 585 (3) (12 May), 554-57.

Ireland, Dáil Debates (2005a) Vol. 596 (1) (26 Jan.), 129-54.

Ireland, Dáil Debates (2005b) Vol. 599 (2) (8 Mar.), 237-46.

Ireland, Dáil Debates (2005c) Vol. 610 (2) (16 Nov.), 491-500.

Ireland, Dáil Debates (2006a) Vol. 620 (2) (24 May), 377-82.

Ireland, Dáil Debates (2006b) Vol. 628 (4) (29/30 Nov.), 13-18.

Ireland, Dáil Debates (2009) Vol. 681 (2) (29 Apr.), 31.

Ireland, Department of Communications, Marine and Natural Resources (2004) Maritime Security Act 2004 Explanatory and Financial Memorandum, Dublin: Department of Communications, Marine and Natural Resources.

Ireland, Department of Defence (2000a) White Paper on Defence, Dublin: Department of Defence.

Ireland, Department of Defence (2000b) Annual Report, Dublin: Department of Defence.

Ireland, Department of Defence (2001a) Strategy Statement 2001-2004, Dublin: Department of Defence.

Ireland, Department of Defence (2001b) 'Defence Estimates 2002' [press release], 14 Nov., available at www.defence.ie [accessed 20 Nov. 2006].

Ireland, Department of Defence (2002a) Annual Report 2001, Dublin: Department of Defence.

Ireland, Department of Defence (2002b) 'Defence Estimates 2003' [press release], 16 Nov., available at www.defence.ie [accessed 20 Nov. 2006].

Ireland, Department of Defence (2004) 'Minister's speech to a Select Committee on the Defence Estimates for 2004', 1 June, available at www.defence.ie/WebSite. 
nsf/Document+ID/B552D65A6A16480F80256EA6004CC56E?editDocument [accessed 17 Feb. 2007].

Ireland, Department of Defence (2005) Strategy Statement 2005-2007, Dublin: Department of Defence.

Ireland, Department of Defence (2006a) 'Air Corps receive first AW 139 helicopter' [press release], 11 Aug., available at www.defence.ie [accessed 12 Aug. 2006].

Ireland, Department of Defence (2006b) 'Defence Estimates 2007' [press release], 19 Nov., available at www.defence.ie [accessed 20 Nov. 2006].

Ireland, Department of Environment, Heritage and Local government (2006) A Framework for Major Emergency Management, available at www.environ.ie [accessed 19 Dec. 2006].

Ireland, Department of Foreign Affairs (1996) Challenges and Opportunities Abroad: White Paper on Foreign Policy, Dublin: Department of Foreign Affairs.

Ireland, Department of Justice, Equality and Law Reform (2002) 'McDowell welcomes general public's satisfaction with An Garda Síochána', [press release], 1 Oct., available at www.justice.ie/80256E01003A02CF/vWeb/pcJUSQ67NKDUen [accessed 18 Dec. 2004].

Ireland, Department of Justice, Equality and Law Reform (2003) Strategy Statement 2003-2005, Dublin: Department of Justice, Equality and Law Reform.

Ireland, Department of Justice, Equality and Law Reform (2005) Criminal Justice (Terrorist Offences) Act 2005 Explanatory Memorandum, Dublin: Department of Justice, Equality and Law Reform.

Ireland, Department of Justice, Equality and Law Reform (2006) 'McDowell very satisfied with outcome of Estimates Process' [press release], 19 Nov., available at: www.justice.ie.80256E01003A02CF/vWeb/pcJUSQ6VLKX4-en [accessed 20 Nov. 2006].

Ireland, Department of Public Enterprise (2001) National Planning for Nuclear Emergencies, Dublin: Department of Public Enterprise.

Ireland, Department of the Taoiseach (1998) Price Waterhouse Report to the Steering Group on the Review of the Irish Naval Service and Air Corps, Dublin: Department of the Taoiseach.

Ireland, Joint Committee of Justice, Equality, Defence and Women's Rights (2005) Interim Report on the Report of the Independent Commission of Inquiry into the Murder of Seamus Ludlow, Dublin: Houses of the Oireachtas.

Irish Council for Civil Liberties (2004) Morris Tribunal - Garda reform must address frightening corruption and bad management [online press release], 16 July, available at http://iccl.ie/DB_Data/press/MorrisTribunalGardareform_74.htm [accessed 01 Feb. 2007].

Irish Independent (2006a) ‘ $€ 100 \mathrm{~m}$ vessel to boost navy strength’ [online], 7 Sept., available at www.unison.ie/irish_independent [accessed 7 Sept. 2006].

Irish Independent (2006b) 'A question of inclusion', 19 Dec., 16.

Irish Refugee Council (2004) Immigration Bill is bad law, say leading human rights and migrant organisations [online press release], 03 Feb., available at www. irishrefugeecouncil.ie [accessed 11 Oct. 2005].

Irish Times (2001a) 'Taoiseach calls for "measured response" by US' [online], 12 Sept., available at www.irishtimes.com [accessed 20 Sept. 2001].

Irish Times (2001b) 'The Northern Dimension' [online], 17 Sept., available at www. irishtimes.com [accessed 20 Jan. 2007].

Irish Times (2002a) 'McCreevy memo points to government deficit' [online], 23 
Sept., available at www.irishtimes.com [accessed 20 Nov. 2006].

Irish Times (2002b) 'Clashes over law and order and the economy dominated last night's television debate' [online], 15 May, available at www.irishtimes.com [accessed 3 Feb. 2007].

Irish Times (2004a) 'EU ministers discuss sharing of anti-terror intelligence' [online], 9 June, available at www.irishtimes.com [accessed 9 June 2004].

Irish Times (2004b) 'Army Reserve to be eligible for foreign duty' [online], 27 July, available at www.irishtimes.com [accessed 10 Oct. 2006].

Irish Times Breaking News (2004) 'Taoiseach confident that Garda will investigate complaints' [online], 9 Jan., available at www.irishtimes.com/newspaper/ breaking/2004/0109/breaking4.htm [accessed 30 Nov. 2006].

Irish Times (2006a) 'Standing of the Garda' [online], 29 Mar., available at www. irishtimes.com [accessed 1 Feb. 2007].

Irish Times (2006b) 'Migrant access' [online], 19 Oct., available at www.irishtimes. com [accessed 19 Oct. 2006].

Irish Times (2007a) 'Upgrade of naval fleet to cost $€ 180 \mathrm{~m}$ ' [online], 6 Jan., available at www.irishtimes.com [accessed 6 Jan. 2007].

Irish Times (2007b) 'Race discrimination' [online], 26 July, available at www.irishtimes.com [accessed 28 July 2007].

Irish Times (2008) 'Human Trafficking' [online], 20 Oct., available at www.irishtimes.com [accessed 22 Oct. 2008].

Ishizuka, K. (1999) 'Ireland and the Partnership for Peace', Irish Studies in International Affairs, Vol. 10, 185-200.

Jackson, P. (2000) Defending Ireland: The Irish State and its Enemies Since 1922, by Eunan O' Halpin, reviewed in Irish Studies in International Affairs, Vol. 11, 247-53.

Jacob, J. (2001) Interview on: Marian Finucane Show, RTÉ Radio 1, 26 Sept., 0900 hrs.

Jackson, M. (2007) Soldier: The Autobiography, London: Bantam.

Jamaica Observer (2006) 'Irish economy is a model to the world' [online], March 03, available at www.jamaicaobserver.com/magazines/Business/html/ 20060302T190000-0500_99765_OBS_IRISH_ECONOMY_IS_A_MODEL_ TO_THE_WORLD.asp [accessed 2 Feb. 2007].

Jane's Sentinel Security Assessments: Western Europe (2002) [online], available at http://sentinel.janes.com [accessed 10 Oct. 2002].

Jeffrey, K. (1996) 'The British Army and Ireland Since 1922', in T. Bartlett and K. Jeffrey (eds), A Military History of Ireland, Cambridge: Cambridge University Press, 431-58.

Joyce, J. and P. Murtagh (1983) The Boss: Charles J. Haughey in government, Dublin: Poolbeg.

Keatinge, P. (1984) A Singular Stance: Irish Neutrality in the 1980s, Dublin: Institute of Public Administration.

Keatinge, P. (1995) Towards a Safer Europe - Small State Security Policies and the European Union: Implications for Ireland, Summary of Interim Report, Dublin: Institute of European Affairs.

Keatinge, P. (1996) European Security: Ireland's Choices, Dublin: Institute of European Affairs.

Keatinge, P. (1998) 'Ireland and European Security: Continuity and Change', Irish Studies in International Affairs, Vol. 9, 31-7. 
Keatinge, P. and Tonra, B. (2002) 'The European Rapid Reaction Force' [online], available at www.iiea.com [accessed 8 Oct. 2002].

Kelly, O. (2004a) 'Gardaí say UK officials have no power here', Irish Times [online], 20 July, available at www.irishtimes.com [accessed 16 Feb. 2007].

Kelly, O. (2004b) 'Gardaí never admit fault, commander told', Irish Times [online], 30 July, available at www.irishtimes.com [accessed 30 July 2004].

Kenny, C. (2003) Fearing Sellafield, Dublin: Gill and Macmillan.

Keogh, D. (1998) Jews in Twentieth Century Ireland: Refugees, Anti-Semitism and the Holocaust, Cork: Cork University Press.

Keogh, D. (2000) 'Irish Neutrality and the First Application for Membership of the EEC', in M. Kennedy and J.M. Skelly (eds), Irish Foreign Policy 1919-1966: From Independence to Internationalism, Dublin: Four Courts Press, 265-85.

Keohane, D. (2001) 'Realigning Neutrality? Irish Defence Policy and the EU' [online], available at: www.weu.int/institute/occasion/occ24.html [accessed 25 Sept. 2001].

Keohane, R.O. (2002a). 'The Public Delegitimation of Terrorism and Coalitional Politics', in K. Booth and T. Dunne (eds), Worlds in Collision: Terror and the Future of Global Order, Hampshire: Macmillan, 141-51.

Keohane, R.O. (2002b) 'The Globalization of Informal Violence, Theories of World Politics and the "Liberation of Fear", International Organization, Spring, 29-43.

Keohane, R.O. and J.S. Nye (1971) Transnational Relations and World Politics, Cambridge MA: Harvard University Press.

Keohane, R.O. and J.S. Nye (1977) Power and Interdependence, Boston: Little Brown.

Keown, G. (2000) 'Taking the World Stage: Creating an Irish Foreign Policy in the 1920s', in M. Kennedy and J.M. Skelly (eds), Irish Foreign Policy 1919-1966: From Independence to Internationalism, Dublin: Four Courts Press, 25-43.

Kyle, K. (2005) 'Anti-war protestors to hold rally in Shannon', Irish Times Breaking News [online], 21 Sept., available at www.irishtimes.com/newspaper/breaking/2005/0921/breaking36.htm [accessed 1 Feb. 2007].

Labanyi, D. (2002) 'Inquiry into alleged Garda corruption approved', Irish Times Breaking News [online], 12 Feb., available at www.irishtimes.com/newspaper/ breaking/2002/0212/breaking52.htm [accessed 30 Nov. 2004].

Lake, A. (2000) Six Nightmares: Real Threats in a Dangerous World and How America Can Meet Them, Boston, New York, London: Little Brown.

Lally, C. (2003a) 'Bin Laden “financier” lives here, says EC', Irish Times [online], 11 June, available at www.irishtimes.com [accessed 14 June 2003].

Lally, C. (2003b) 'Defence Forces defer industrial action decision', Irish Times [online], 9 Oct., available at www.irishtimes.com [accessed 12 Oct. 2003].

Lally, C. (2005) 'Call for increase in Army's Rangers', Irish Times [online], 6 Sept., available at www.irishtimes.com [accessed 22 Nov. 2005].

Lally, C. (2006a) 'Shake-up of Garda informer system', Irish Times [online], 25 Apr., available at www.irishtimes.com [accessed 26 Apr. 2006].

Lally, C. (2006b) 'Asylum seeker numbers set to hit 10-year low', Irish Times [online], 7 Sep, available at www.irishtimes.com [accessed 7 Sept. 2006].

Lally, C. and M. Hennessy (2004) 'Commissioner concerned at retired judge's allegations', Irish Times [online], 09 Jan., available at www.irishtimes.com [accessed 12 Jan. 2004]. 
Lally, C. (2007a) 'Garda may alter foreign recruitment rules', Irish Times [online], 27 July, available at www.irishtimes.com [accessed 28 July 2007].

Lally, C. (2007b) 'Civilian role urged in running of Garda, Irish Times, 14 Sept., 1.

Lally, C. and R. Mac Cormaic (2006) 'Two terror suspects have Irish links', Irish Times [online], 22 Aug., available at www.irishtimes.com [accessed 20 Dec. 2006].

Lavery, D. (2006) 'Navy chiefs set their sights on two new ships', Irish Independent [online], 2 May, available at www.unison.ie/irish_independent [accessed 2 May 2006].

Laqueur, W. (2002) The New Terrorism: Fanaticism and the Arms of Mass Destruction, London: Phoenix.

Lee, J.J. (1989) Ireland 1912-1985: Politics and Society, Cambridge: Cambridge University Press.

Lenihan, C. (2007) Interview on: 9 O’Clock News, RTÉ 1, 12 Aug., 2110 hrs.

Linklater, A. (1996a) 'Marxism', in S. Burchill, A. Linklater, R. Devetak, M. Paterson and J. True (eds), Theories of International Relations, Hampshire and London: Macmillan, 119-44.

Linklater, A. (1996b) 'Realism', in S. Burchill, A. Linklater, R. Devetak, M. Paterson and J. True (eds), Theories of International Relations, Hampshire and London: Macmillan, 67-92.

Little, R. and M. Smith (eds) (1991) Perspectives in World Politics, (2nd edn) London and New York: Routledge.

Lynch, F. and M. Mellett (2004) 'Countering Asymmetric Threats at Sea - The Role of Post Modern Naval Forces', Defence Forces Review, Vol. 2, 65-79.

Lynch, T.J. (2003) 'Gerry Adams Visa in Anglo-American Relations', Irish Studies in International Affairs, Vol. 14, 33-44.

Lyons, F.S.L. (1973) Ireland Since the Famine, paperback edn, London: Fontana.

Mac Ginty, R. (1999), 'Decommissioning in the Transition from War to Peace in Northern Ireland', Irish Studies in International Affairs, Vol. 10, 237-47.

McCaffrey, M. (2005) 'Islamic cleric says Ireland's a "legitimate target", Belfast Telegraph [online], 17 Aug., available at www.belfasttelegraph.co.uk [accessed 20 Aug. 2005].

McConnell, M. (2007) 'Overhauling intelligence', Foreign Affairs [online], July/Aug., available at www.foreignaffairs.org [accessed 10 Aug. 2007].

McDonagh, M. (2005) 'Fire chiefs turn up heat on government', Irish Independent [online], 5 May, available at www.unison.ie/irish_independent [accessed 6 May 2005].

McDonald, O.A.K. (1998) 'Recent Developments in Peacekeeping - The Irish Experience', in E. Moxon-Browne (ed.), A Future for Peacekeeping? Hampshire: Macmillan, 40-57.

Mc Evoy, S. (2000) 'Communities and Peace: Catholic Youth in Northern Ireland', Journal of Peace Research, Vol. 37 (1), 85-103.

McGladdery, G. (2002) 'Perceptions of "Siege Mentality": Northern Irish Protestants and White South Africans in the New Political Dispensation', Irish Studies in International Affairs, Vol. 13, 87-103.

McMahon, G. (2000) 'Battlefield from Defence White Paper is left strewn with victims', Irish Times [online], 1 Mar., available at www.irishtimes.com [accessed 10 Feb. 2003].

McNiffe, L. (1997) A History of the Garda Síochána: A Social History of the Force 
1922-52 with an Overview for the Years 1952-97, Dublin: Wolfhound.

McSweeney, B. (1985) 'Postscript: The case for active Irish neutrality', in B. McSweeney (ed.), Ireland and the Threat of Nuclear War, Dublin: Dominican Publications.

McSweeney, B. (1998) 'Identity, Interest and the Good Friday Agreement', Irish Studies in International Affairs, Vol. 9, 93-102.

McSweeney, B. (1999) Security, Identity and Interests: A Sociology of International Relations, Cambridge, New York and Melbourne: Cambridge University Press.

Maguire, J. (2002) Defending Peace: Ireland's Role in a Changing Europe, Cork: Cork University Press.

Manning, M. (2004) 'A reformed Garda could be among the best in the world', Irish Times [online], 24 July, available at www.irishtimes.com [accessed 24 July 2004].

Manning, M. (2007) 'Speech of Dr Maurice Manning, President, Irish Human Rights Commission at the launch of the IHRC Annual Report 2006' [online], 11 Sept. 2007, available at www.ihrc.ie/_fileupload/banners/SpeechMauriceAn nualReport2006.doc [accessed 12 Sept. 2007].

March, J.G. and J.P. Olsen (1996) 'Institutional Perspectives on Political Institutions', Governance: An International Journal of Policy and Administration, Vol. 9 (3), 247-64.

Mason, J. (2002) Qualitative Researching, London, Thousand Oaks, New Delhi: Sage.

Matthew, B., A. Miles and B. Huberman (1994) Qualitative Data Analysis, 2nd edn, Thousand Oaks, London, New Delhi: Sage.

Maxwell, J.A. (1998) 'Designing a Qualitative Study', in L. Bickerman and D.J. Rog (eds), Handbook of Applied Social Research Methods, Thousand Oaks, London, New Delhi: Sage.

Meehan, E. (2000a) 'Free movement between Ireland and the UK: from the "common travel area" to The Common Travel Area, Dublin: The Policy Institute in association with the Department of Justice, Equality and Law Reform.

Meehan, E. (2000b) 'Britain’s Irish question or Britain's European question? BritishIrish relations in the context of the European Union and the Belfast Agreement', Review of International Studies, Vol. 26 (3), 83-97.

Meehan, E (2000c) 'Bringing in Europe: the Peace Process and the Europeanisation of the Irish Question, Irish Studies in International Affairs, Vol. 11, 179-91.

Mellett, M. (2005) 'The "Blue-Green" Ship - Yes or No', An Cosantóir, December, 7-11.

Migrants Rights Centre and Dublin City Development Board (2007) Realising Integration: Migrant Workers Undertaking Essential Low Paid Work in Dublin City, Dublin: MRCI/Dublin City Development Board.

Millar, F. “'Gaping hole” in UK e-border defences', Irish Times [online], 09 Feb., available at www.irishtimes.com [accessed 10 Apr. 2009].

Millar, F. (2008) 'Travellers to Britain must carry photo ID under new legislation', Irish Times [online], 18 July, available at www.irishtimes.com [accessed 18 July 2008].

Miller, R. (2005) 'From 11 September to the war in Iraq: Irish responses to the global 'war on terrorism', Irish Studies in International Affairs, Vol. 16, 155-74.

Moloney, E. (2002) A Secret History of the IRA, London: Allen Lane. 
Molony, S. (2006) 'Identity cards plan in UK to bring decision closer here', Irish Independent [online], 23 Jan., available at www.unison.ie/irish_independent [accessed 23 Jan. 2006].

Mooney J. and M. O' Toole (2003) Black Operations: The Secret War Against the Real IRA, Meath: Maverick House.

Moran, P.J. (1998) 'Training and Education in the Garda Síochána', Communique, June, 3-7.

Morse, J.M. (1994) Qualitative Research Methods, California, London and New Delhi: Sage.

Mouritzen, H. (1997) 'Kenneth Waltz: A critical rationalist between international politics and foreign policy', in I.B. Neumann and O. Wæver (eds), The Future of International Relations: Masters in the Making? London and New York: Routledge, 66-89.

Moxon-Browne, E. (1998) 'A Future for Peacekeeping', in E. Moxon-Browne (ed.), A Future for Peacekeeping? Hampshire: Macmillan, 192-201.

Mullan, D. (2000) The Dublin and Monaghan Bombings, Dublin: Wolfhound.

Mulqueen, M. (2003) 'The Paradigms of Security on the Sidelines: International Relations Theory and Small States in the Post-September 11 Risk Environment', paper presented to the Annual Conference of the British International Studies Association, Birmingham, 17 Dec. 2003.

Mulqueen, M. (2005) 'United We Stand? EU Counter Terrorism Initiatives Meet a Small Member State's Security Community', paper presented to the 46th Annual Convention of the International Studies Association, Hawaii, USA, 5 Mar. 2005.

Mulqueen, M. (2006) 'Under-siege officers just resort to circling the wagons again', Irish Independent [online], 21 July, available at www.unison.ie [accessed 3 Feb. 2007].

Mulqueen, M. (2007) 'A Weak Link? Irish National Security Policy on International Terrorism', Contemporary Security Policy, Vol. 28 (2), 330-56.

Murphy, J.A. (2000) 'Irish neutrality in historical perspective', in B. Girvin and G. Roberts (eds), Ireland and the Second World War: Politics, Society and Remembrance, Dublin: Four Court Press, 9-23.

Murphy, R. (2002) 'Ireland, Peacekeeping and Defence Policy', in B. Tonra and E. Ward (eds), Ireland in International Affairs: Interests, Institutions and Identities, Dublin: Institute of Public Administration, 13-45.

Murphy, R. (2007) UN Peacekeeping in Lebanon, Somalia and Kosovo: Operational and Legal Issues in Practice, Cambridge: Cambridge University Press.

Murray, N. (2000) 'Smith stresses importance of military's security duties', Irish Examiner [online] 8 Sept., available at http://archives.tcm.ie/irishexaminer/2000/09/08/current/i_text.htm [accessed 3 Feb. 2007].

National Forum on Europe (2002) Report of Proceedings, 13: EU Common Foreign and Security Policy, Dublin: The Stationary Office.

Naval Service (1999) Naval Service, New Organisation VFM Implementation Plan, Cork: Naval Service.

North Atlantic Treaty Organisation [NATO] (1997) NATO Logistics Handbook [online], available at www.nato.int/docu/logi-en/1997/defini.htm [accessed 28 Sept. 2007].

North Atlantic Treaty Organisation [NATO] (2001) NATO Handbook, Brussels: NATO Office of Information and Press. 
Neff, S.C. (2000) The Rights and Duties of Neutrals: A General History, Manchester: Manchester University Press.

Newman, C. (2006) 'Defence funding set to rise above $€ 1$ bn for first time', Irish Times [online], 17 Nov., available at www.irishtimes.com [accessed 20 Nov. 2006].

Nye, J.S. (2002) The Paradox of American Power: Why the World's Only Superpower Can't go it Alone, New York: Oxford University Press.

O' Boyce, M. (2006) 'From the top', Garda Review, September, 14-15.

O' Brien, B. (1999) The Long War: The IRA and Sinn Féin, 2nd edn, Dublin: O’ Brien Press.

O’ Brien, C. (2007) 'UK Sikh policy body criticised Garda rule', Irish Times, 21 August, 5.

O’ Brien, T. (2004) 'State may take back iodine tablets issued to homes', Irish Times [online], 27 Mar., available at www.irishtimes.com [accessed 30 Mar. 2004].

O' Brien, T. (2006) 'New emergency unit planned to tackle crisis', Irish Times [online], 04 May, available at www.irishtimes.com [accessed 4 May 2006].

O' Connor, A. (2001a) 'Emergency plans for nuclear attack updated', Irish Times [online], 27 Sept., available at www.irishtimes.com [accessed 27 Sept. 2001].

O' Connor, A. (2001b) 'New office to co-ordinate response to any future attacks', Irish Times [online], 04 Oct., available at www.irishtimes.com [02 Feb. 2007]. O' Connor, A. and M. Minihan (2001) 'Fears of possible attack discounted', Irish Times [online], 26 Sept., available at www.irishtimes.com [accessed 26 Sept. 2001].

O' Halloran, M. (2004a) 'Bill would create "a nation of spies", says Fine Gael', Irish Times [online], 5 Feb., available at www.irishtimes.com [accessed 5 Feb. 2004].

O' Halloran, M. (2004b) 'Shannon stopover "not a threat”, Irish Times [online], 24 Nov., available at www.irishtimes.com [accessed 28 Nov. 2004].

O' Halloran, M. (2007a) 'Lenihan says all races must feel welcome', Irish Times [online], 20 July, available at www.irishtimes.com [accessed 23 July 2007].

O’ Halloran, M. (2007b) 'Extending welfare warning', Irish Times [online], 19 Oct., available at www.irishtimes.com [accessed 19 Oct. 2007].

O’ Halpin, E. (1995) 'According to the Irish minister in Rome ...': British decrypts and Irish diplomacy in the Second World War, Irish Studies in International Affairs, Vol. 6, 95-105.

O' Halpin, E. (1996) 'The army in independent Ireland', in T. Bartlett and K. Jeffrey (eds), A Military History of Ireland, Cambridge: Cambridge University Press, 407-30.

O’ Halpin, E. (1999) Defending Ireland: The Irish State and its Enemies Since 1922, Oxford: Oxford University Press.

O' Halpin, E. (2000a) 'Irish-Allied security relations and the "American Note" crisis: new evidence from British records', Irish Studies in International Affairs, Vol. $11,71-83$.

O' Halpin, E. (2000b) 'MI5's Irish Memories: Fresh Light on the Origins and Rationale of Anglo-Irish Security Liaison in the Second World War', in B. Girvin and G. Roberts (eds), Ireland and the Second World War: Politics, Society and Remembrance, Dublin: Four Courts Press.

O' Halpin, E. (2001) 'Northern Ireland: the Troubled Peace Process', (review article), Irish Studies in International Affairs, Vol. 12, 243-7. 
O' Halpin, E. (2002) 'Ireland and EU Intelligence Assessment: The Politics of an Undeclared Petersberg Task', Irish Political Studies, Vol. 17 (1), 35-58.

O’ Halpin, E. (2003a) MI5 and Ireland, 1939-1945: The Official History, Dublin: Irish Academic Press.

O’ Halpin, E. (2003b) 'Long Fellow, Long Story: MI5 and de Valera', Irish Studies in International Affairs, Vol. 14, 185-203.

O' Halpin, E. (2008) Spying on Ireland: British Intelligence and Irish Neutrality During the Second World War, Oxford: Oxford University Press.

Olson, W.C. and A.J.R. Groom (1991) International Relations Then and Now: Origins and Trends in Interpretation, London: Harper Collins Academic.

O’ Mahony, P. (2004a) Reflections by the Irish Refugee Council on World Refugee Day [online press release], 20 June, available at www.irishrefugeecouncil.ie [accessed 1 Aug. 2005].

O’ Mahony, P. (2004b) Open letter to Mr. Michael McDowell, Minister for Justice, Equality and Law Reform [press release], 19 July, available at www.irishrefugeecouncil.ie [accessed 3 Aug. 2005].

O' Neill, J.T. and N. Rees (2005) United Nations Peacekeeping in the Post Cold War Era, New York: Routledge.

O' Regan, E. and B. Heffernan (2008) 'Public can dump anti-nuke pills', Irish Independent [online], 4 Apr., available at www.independent.ie [accessed 6 Apr. 2008].

O’ Regan, M. (2005) 'Minister does not recall reading Elukanlo file', Irish Times [online], 13 Apr., available at www.irishtimes.com [accessed 16 Aug. 2005].

O’ Riordan, P.A. (1992) Emergency Planning in Ireland, Dublin: Institute of Public Administration.

O' Shea, B. (ed.) (2001) In the Service of Peace: Memories of Lebanon, Dublin: Mercier.

O’ Sullivan, M. (1994) Sean Lemass: A Biography, Dublin: Blackwater.

O’ Toole, M. (2004) 'Iraq rebels recruit Irish fighters', The Irish Daily Star, 9 June, 1.

Parekh, B. (2002) 'Terrorism or Intercultural Dialogue', in K. Booth and T. Dunne (eds), Worlds in Collision: Terror and the Future of Global Order, Hampshire: Palgrave Macmillan, 270-83.

Parker, C.F. and E.K. Stern (2002) 'Strategic Surprise? Learning from September 11', in Bengt Sundelius (ed.), The Consequences of September 11: A Symposium on the Implications for the Study of International Relations, Stockholm: The Swedish Institute of International Affairs, 67-89.

Permanent Defence Forces Other Ranks Representative Association [PDFORRA] (1996) Submission Document to Select Oireachtas Committee on Legislation and Security, Dublin: PDFORRA.

Peterson, V.S. (1997) 'Seeking World Order Beyond the Gendered Order of Global Hierarchies', in R.W. Cox (ed.), The New Realism: Perspectives on Multilateralism and World Order, Tokyo, New York: United Nations University Press, 38-56.

Pierson, P. and T. Skocpol (2003), 'Historical Institutionalism in Contemporary Political Science', in I. Katznelson and H.V. Milner (eds), Political Science: The State of the Discipline, Washington, New York, London: American Political Association and W.W. Norton, 693-721.

Porter, S. (2002) 'Critical Realist Ethnography', in T. May (ed.), Qualitative Research in Action, London: Sage.

Rees, N. (2000) 'The Kosovo Crisis, the International Response and Ireland', Irish 
Studies in International Affairs, Vol. 11, 55-70.

Regan, J.M. (1999) The Irish Counter-Revolution 1921-1936, Dublin: Gill and Macmillan.

Reid, L. (2005a) 'Senator critical of Garda reforms Bill', Irish Times [online], available at www.irishtimes.com [accessed 20 July 2005].

Reid, L. (2005b) 'State watches about 24 Islamic suspects', Irish Times [online], 14 July, available at www.irishtimes.com [accessed 2 Feb. 2007].

Reid, M. (1998) 'A History of the Detective Branch in Ireland 1843-1998 - An Overview', Communique, September, 3-10.

Representative Association of Commissioned Officers [RACO] (1996) Review of the Air Corps: Submission to Price Waterhouse Consultants, Dublin: RACO.

Representative Association of Commissioned Officers [RACO] (1998) Defending the Future: Defence White Paper Submission, Dublin: RACO.

Reuters (2004) 'UN Anti-Terror Head Wants More Intelligence Sharing' [online], 20 Oct., available at www.reuters.com/printerFriendlyPopup.jtml?type=world News\&storyID=6557257 [accessed 21 Oct. 2004].

Rogers, P. (2003) “'The War on Terror”: Current status and possible development', paper presented to the Annual Conference of the British International Studies Association (BISA), Birmingham, 17 Dec. 2003.

RTÉ News [online] (2004a) '1,000 US troops pass through Shannon daily', 18 Oct., available at www.rte.ie/news/2004/1018/shannon.html [accessed 15 Feb. 2005].

RTÉ News [online] (2004b) 'Court bid to jail Conroy over deportations', 16 Aug., available at www.rte.ie./news/2004/0816/deportation.html [accessed 17 Aug. 2004].

RTÉ News [television text] (2006) 'Air Corps to get new helicopters', 23 Dec., 1144 hrs.

RTÉ News [online] (2007a) 'Report highlights migrant issues in Dublin', 27 Sept., available at www.rte.ie/news/2007/0927/integration.html [accessed 28 Sept. 2007].

RTÉ News [online PDA edition] (2007b) 'Passports may be needed to travel to Britain', 24 Oct., available at www.rte.ie

Ryder, C. (2000) The RUC 1922-2000: A Force Under Fire, 5th edn, London: Arrow.

Sageman, M. (2004) Understanding Terror Networks, Pennsylvania: University of Pennsylvania Press.

Sageman, M. (2005) 'Understanding Jihadi Networks', Strategic Insights [online], Vol. IV (4), available at www.ccc.nps.navy.mil/si/2005/apr/sagemanApr05.asp [accessed 10 Mar. 2006].

Sageman, M. (2008) Leaderless Jihad: Terror Networks in the Twenty-First Century, Philadelphia: University of Pennsylvania Press.

Salmon, T. (1989) Unneutral Ireland, an Ambivalent and Unique Security Policy, Oxford: Clarendon Press.

Sandler, T. and W. Enders (2004) 'An Economic Perspective on Transnational Terrorism', European Journal of Political Economy, Vol. 20 (2), 301-16.

Sheahan, F. (2006) 'Passports go hi-tech ... but no fingerprints', Irish Independent [online], 17 Oct., available at www.unison.ie/irish_independent [accessed 17 Oct. 2006].

Simpson, A.W. (2003) 'European Micro-states and International Politics; in Theory 
and in Practice', paper presented at the British International Studies Association (BISA) Conference 2003, University of Birmingham, 16 Dec. 2003.

Skelly, J.M. (1996) Irish Diplomacy at the United Nations 1945-1965: National Interests and the International Order, Dublin: Irish Academic Press.

Skelly, J.M. (2000) 'National Interests and International Mediation: Ireland's South Tyrol Initiative at the United Nations, 1960-1', in M. Kennedy and J.M. Skelly (eds), Irish Foreign Policy 1919-1966: From Independence to Internationalism, Dublin: Four Courts Press, 286-307.

Smith, D. (1990) 'Beyond contingency planning: towards a model of crisis management', Organization and Environment, Vol. 4(4), 263-75.

Smith, J.A. (1995) 'Semi-structured interviewing and qualitative analysis', in J.A. Smith, R. Harré and L. Van Langenhove (eds), Rethinking Methods in Psychology, London, Thousand Oaks, New Delhi: Sage.

Smith, M. (2004) Interview on: Today with Pat Kenny, RTÉ Radio 1, 31 Mar., 1000 hrs.

Smith, M.L.R. (1998), 'Peace in Ulster? A Warning from History', Jane’s Intelligence Review [online], 1 July, available at http://jir.janes.com [accessed 28 Nov. 2004).

Smith, M.L.R. and M. von Tangen Page (2001) 'Lessons from long Good Friday', Jane's Intelligence Review [online] 01 Apr., available at http://jir.janes.com [accessed 28 Nov. 2004].

Smith, R. (1980) Under the Blue Flag, Dublin: Aherlow.

Smyth, J. (2008) 'EU body finds race crime on the increase', Irish Times [online], 25 June, available at www.irishtimes.com [accessed 25 June 2008].

Sreenan, J. (2005) 'Address by Lt Gen J. Sreenan, chief of staff, to the RACO Biennial Delegate Conference, Cavan Crystal Hotel, 30 Nov'. [online], available at www. military.ie [accessed 10 Dec. 2005].

Strasser, S. (1985) Understanding and Explanation: Basic Ideas Concerning the Humanity of the Human Sciences, Pittsburgh: Duquesne University Press.

Sweeney, C. (2006) 'Only one in 10 of asylum claims are granted', Irish Independent [online], 20 Apr., available at www.unison.ie/irish_independent [accessed 21 Apr. 2006].

Taylor, C. (2003) 'Ireland ranked as the most globalised of 62 states due to exports', Irish Times [online], 8 Jan., available at www.irishtimes.com [accessed 5 Sept. 2006].

Thelen, K. (2002) 'The Explanatory Power of Historical Institutionalism', in R. Mayntz (ed.), Akteure - Mechanismen - Modelle: Zur Theoriefähigkeit makrosozialer Analysen, Frankfurt, New York: Campus Verlag.

Tonge, J. (1998) Northern Ireland: Conflict and Change, 2nd edn, Essex: Pearson Longman.

Tonra, B. (2000) The Europeanisation of National Foreign Policy: Dutch, Danish and Irish Foreign Policy in the European Union, Hampshire: Ashgate.

Tonra, B. (2002) 'Irish Foreign Policy', in W. Crotty and D.E. Schmitt (eds), Ireland on the World Stage, Essex: Pearson Education.

Tribunal of Inquiry Set up Pursuant to the Tribunal of Inquiry (Evidence) Acts 1921-2002 into Certain Gardaí in the Donegal Division (2004) Report on Explosives 'Finds' in Donegal, Dublin: Government Publications.

Tribunal of Inquiry Set up Pursuant to the Tribunal of Inquiry (Evidence) Acts 1921-2002 into Certain Gardaí in the Donegal Division (2005) Report on the 
investigation into the death of Richard Barron and the extortion calls to Michael and Charlotte Peoples, Dublin: government Publications.

Tribunal of Inquiry Set up Pursuant to the Tribunal of Inquiry (Evidence) Acts 1921-2002 into Certain Gardaí in the Donegal Division (2006a) Report on the circumstances surrounding the arrest and detention of Mark McConnell on October 11998 and Michael Peoples on May 6 1999, Dublin: Government Publications.

Tribunal of Inquiry Set up Pursuant to the Tribunal of Inquiry (Evidence) Acts 1921-2002 into Certain Gardaí in the Donegal Division (2006b) Report into allegations relating to the Garda investigation of an arson attack on property situated on the site of the telecommunications mast at Ardara, County Donegal in November 1996, Dublin: government Publications.

Tribunal of Inquiry Set up Pursuant to the Tribunal of Inquiry (Evidence) Acts 1921-2002 into Certain Gardaí in the Donegal Division (2006c) Report on the arrest and detention of 7 persons at Burnfoot, County Donegal on May 231998 and the investigation relating to same, Dublin: government Publications.

Tribunal of Inquiry Set up Pursuant to the Tribunal of Inquiry (Evidence Acts) 1921-2002 (2006d) Report of the Tribunal of Inquiry into the facts and circumstances surrounding the fatal shooting of John Carthy at Abbeylara, Co. Longford on 20th April, 2000, Dublin: government Publications.

Tseëlon, E. (2001) 'Ontological, Epistemological and Methodological Clarifications in Fashion Research: From Critique to Empirical Suggestions', in A. Guy, E. Green and M. Banim (eds), Through the Wardrobe: Women's Relationships with Their Clothes, London and New York: Berg.

United Kingdom, Cabinet Office (2003) Draft Civil Contingencies Bill Consultation Document - June 2003, London, Cabinet Office.

United Kingdom, Committee of Privy Counsellors (2004) Review of Intelligence on Weapons of Mass Destruction, London: House of Commons.

United Kingdom, Ministry of Defence (2006) Operation Banner: An Analysis of Military Operations in Northern Ireland [online], available at www.patfinucanecentre.org/misc/opbanner.pdf [accessed 1 Sept. 2007].

United States, Senate Select Committee on Intelligence and House Permanent Select Committee on Intelligence (2002) Joint Inquiry into Intelligence Community Activities Before and After the Terrorist Attacks of September 11, 2001, Washington: Senate Select Committee on Intelligence and House Permanent Select Committee on Intelligence.

Von Hippel, K. (2002) 'The Roots of Terrorism: Probing the Myths', in L. Freedman (ed.), Superterrorism: Policy Responses, Massachusetts, Oxford, Victoria and Berlin: Blackwell Publishing, 25-39.

Walker, R.B.J. (1993) Inside/Outside: International Relations as Political Theory, Cambridge: Cambridge University Press.

Wall, M. (2005) 'Secret Service fund open to all ministers, PAC told', Irish Times [online], 11 Feb., available at www.irishtimes.com [accessed 18 Feb. 2005].

Wall, M. (2006a) 'Tánaiste advised to continue supply of iodine pills', Irish Times [online], 21 Apr., available at www.irishtimes.com [accessed 23 Apr. 2006].

Wall, M. (2006b) 'Chinese isolated in Ireland, says study', Irish Times [online], 30 Nov., available at www.irishtimes.com [accessed 30 Nov. 2006].

Walsh, D.P.J. (1998) The Irish Police: A Legal and Constitutional Perspective, Dublin: Round Hall Sweet and Maxwell. 
Waltz, K.N. (1959) Man, the State and War, New York: Colombia University Press.

Waltz, K.N. (1979) Theory of International Politics, Reading: Addison-Wesley.

Waltz, K.N. (2002) 'The Continuity of International Politics', in K. Booth and T. Dunne (eds), Worlds in Collision: Terror and the Future of Global Order, Hampshire: Palgrave Macmillan, 348-53.

Ward, A.J. (1994) The Irish Constitutional Tradition: Responsible government and Modern Ireland 1782-1992, Washington DC: The Catholic University of America Press.

Ward, N. (2006a) 'Morris conclusions claim to go far beyond Donegal boundary', Garda Review, September, 4-5.

Ward, N. (2006b) 'The Commissioner in conversation', Garda Review, September, $6-8$.

West, A. (2004) 'Personal Message From the Chief Of The Naval Staff, Admiral Sir Alan West, To The Royal Navy, 21-July-2004' [online], available at www.royalnavy.mod.uk/rn/news [accessed 10 Nov. 2005].

Whelan, R. (2006) 'Bakri's threat a wake-up call for Ireland', Irish Times [online], 21 Nov., available at www.irishtimes.com [accessed 22 Nov. 2006].

Wylie, P. (2000) “'The Virtual Minimum”: Ireland's Decision for De Facto Recognition of Israel, 1947-9', in M. Kennedy and J.M. Skelly (eds), Irish Foreign Policy 1919-1966: From Independence to Internationalism, Dublin: Four Courts Press, $137-54$.

Zappone, K. and Farrell, M. (2009) 'Cutbacks in the area of human rights are excessive and unfair', Irish Times [online], available at www.irishtimes.com [accessed 7 Apr. 2009].

\section{Articles of the 1937 Constitution}

Article 2

Article 13

\section{Acts of the Oireachtas}

Criminal Justice (Terrorist Offences) Act 2005

Criminal Justice Acts (various)

Defence Act 1954

Defence (Amendment) Act 1993

Garda Síochána Act 1924

Garda Síochána Act 2005

The Illegal Immigrants (Trafficking) Act 2000

Immigration Act 2003

Immigration Act 2004

Irish Nationality and Citizenship Act 2004

Ministers and Secretaries Act 1924

Offences Against the State Acts 1939- 89

Police Forces Amalgamation Act 1925

Public Order Act 1924

Public Service Management Act 1997

Refugee Act 1996 
Web sites of the Irish, Danish, Norwegian, Finnish, and Swedish agencies

\section{Ireland}

Garda Síochana www.garda.ie

Defence Forces www.military.ie

Norway

PST www.pst.politiet.no

FE www.mil.no/etjenesten/english/start/

Sweden

SAPO www.sakerhetspolisen.se

MUST www.hkv.mil.se

Denmark

PETwww.pet.dk

DDIS forsvaret.dk/FE/eng/

\section{Finland}

SUPO www.poliisi.fi/poliisi/supo/home.nsf

GSID www.mil.fi 